\title{
Towpik E. IF-mania: Journal Impact Factor nie jest właściwym wskaźnikiem oceniania wyników badań naukowych, indywidualnych uczonych ani ośrodków badawczych. Nowotwory J Oncol 2015; 65: 465-475 Głos w dyskusji
}

\author{
Andrzej Kajetan Wróblewski
}

Invited commentary

\begin{abstract}
Profesor Edward Towpik wykonał imponującą pracę, przeglądając systematycznie literaturę w celu sporządzenia przeglądu artykułów na temat Journal Impact Factor, bezsensownego wskaźnika narzucanego naukowcom przez biurokratów.
\end{abstract}

Zamieszczona w artykule lista jest długa, choć obejmuje tylko część literatury na ten temat. Dla przykładu podam, że z moich licznych wypowiedzi na ten temat wymieniony jest tylko list do Gazety Wyborczej, przedrukowany w Nowotworach (pozycja 4. w bibliografii). Nie zostały wspomniane moje artykuły: 1) Ostrożnie z tym współczynnikiem. Forum Akademickie 1998, nr 7-8; 2) Apeluję o rozsądek. Forum Akademickie 2002, nr 3, s. 28-30; 3) Bibliometryczna trylogia. Zagadnienia Naukoznawstwa, 2002, nr 1-2, s. 7-29; 4) A commentary on misuses of the impact factor. Arch Immunol Ther Exp 2008; 56, s. 355- 556); 5) Nowe prace Syzyfa. PAUza Akademicka 2015, nr 282.

Wymieniam te artykuły, żeby podać odnośniki dla tych czytelników, którzy być może zechcą zajrzeć do tych tekstów. Podałem tam (w artykulach 2-4) m.in. proste, graficzne uza- sadnienie tego, że potoczne wyobrażenia o znaczeniu JIF są niezgodne z prawdą. Mój diagram był od tego czasu parokrotnie przedrukowywany przez innych autorów. W artykule 5. podałem przekonywające argumenty, że JIF czasopisma ma niewiele wspólnego z liczbą cytowań większości drukowanych tam prac. Łatwo można bowiem udowodnić, że znaczna część artykułów w czasopiśmie o wysokim JIF ma mniej cytowań niż artykuły w czasopiśmie kilka razy mniejszym!

Mam nadzieję, że zmasowany wysiłek nas wszystkich, którzy kierujemy się rozsądkiem i zrozumieniem, w końcu doprowadzi do sukcesu i impact factor znajdzie się w magazynie osobliwości.

\section{Prof. dr hab. Andrzej Kajetan Wróblewski} członek rzeczywisty Polskiej Akademii Nauk wiceprezes Polskiej Akademii Umiejętności dziekan Wydziału Fizyki Uniwersytetu Warszawskiego 1986-89 Rektor Uniwersytetu Warszawskiego 1989-93 przewodniczący Rady Naukowej Instytutu Historii Nauki PAN (od 1976) doktor honoris causa Uniwersytetów w: Siegen, Chapman, Glasgow i Politechniki Warszawskiej e-mail:Andrzej-Kajetan.Wroblewski@fuw.edu.pl 